Acta Linguistica Petropolitana. 2021. Vol. 17.1. P. 441-457

DOI 10.30842/alp23065737171441457

\title{
Inanimate demonstrative pronouns in Kullui (Indo-Aryan)
}

\section{E. A. Renkovskaya}

Institute of Linguistics, Russian Academy of Sciences (Moscow, Russia); jennyrenk@gmail.com

Abstract. The article deals with two inanimate demonstratives in Kullui, an IndoAryan language of Himachali group - the proximal $\tilde{u} i$ and the distal tũi. They have not been previously studied and are not even mentioned in practically a half of the grammatical descriptions of Kullui. The present data comes from the field work conducted in the Kullu district (Himachal Pradesh, India) in 2014-2018.

As far as can be judged, the demonstrative systems of the majority of New Indo-Aryan languages are based on three reflexes of Old Indo-Aryan demonstratives, one proximal and two distal. The proximal demonstratives are considered to go back to the OIA esa 'this'. The two distal demonstratives are derived from the OIA $s a$ (non-direct stem $t a-$ ) 'that' and asau (OBL amu-) 'that'. The presence of two distal demonstratives in NIA languages naturally leads to functional competition between them. As a result, one of the two usually serves as a distal pronoun, while the other either acquires an additional meaning or is completely lost.

Inanimate demonstratives, existing in Kullui alongside animate demonstratives, can refer to inanimate nouns, verbal phrases, or sentential arguments. In other Himachali languages, we find inanimate demonstratives with similar functions that etymologically go back to OIA neuter demonstrative pronouns. Since in the majority of Himachali languages the nominal system does not distinguish neuter gender, the neuter demonstratives acquire a set of new functions.

However, the inanimate demonstratives in Kullui show no neuter-pronoun heritage. While the other Kullui demonstratives derive from the OIA pronouns eșa (proximal) and $s a$ (distal), the inanimate proximal demonstrative $\tilde{u} i$ goes back to the OIA distal pronoun asau, with the distal pronoun tũi formed directly from $\tilde{u} i$ by analogy. Presumably, the reason is that after Kullui had lost its neuter demonstratives, under the influence of neighbouring genetically related languages that retained these demonstratives, their functions have been taken over by the previously little used reflex of asau. 
Keywords: demonstrative pronouns, inanimate pronouns, neuter gender, contact influence, New Indo-Aryan languages, Himachali, Kullui.

Acknowledgments: The research was supported by the Russian Foundation for Basic Research, project No. 19-012-00355.

\section{Неодушевленные указательные местоимения в языке куллуи}

\section{Е. А. Ренковская}

Институт языкознания РАН (Москва, Россия); jennyrenk@gmail.com

Аннотация. В статье рассматриваются неодушевленные указательные местоимения в индоарийском языке куллуи, их происхождение и функции. Если в других языках химачали такие местоимения имеют общую с одушевленными этимологию и представляют собой рефлексы древнеиндийских местоимений среднего рода (etad и $t a d$ ), то в куллуи они имеют иное происхождение. Предположительно, куллуи утратил собственные местоимения среднего рода, однако под влиянием соседних близкородственных языков функции таких местоимений перешли к рефлексам другого древнеиндийского местоимения (asau).

Ключевые слова: указательные местоимения, неодушевленные местоимения, средний род, контактное влияние, новоиндоарийские языки, химачали, куллуи.

\section{Introduction}

The paper deals with inanimate demonstrative pronouns in Kullui language. Kullui is an Indo-Aryan language of the Himachali (formerly, Western Pahari) group of languages. It is spoken in the Kullu district of the state of Himachal Pradesh, India. The work builds on data, collected during my four field trips to the Kullu district in 2014-2018 
in the Kullu Tehsil (the town of Kullu, the villages of Naggar, Bashing, Katrain, Jagatsukh, Suma, Bhalyani) and the Manali Tehsil (the town of Manali, the villages of Kanyali, Barua, Shanag). Inanimate demonstratives in Kullui have not been previously studied and, moreover, are not even mentioned in practically a half of the grammatical descriptions of Kullui; cf. [Diack 1896; Bailey 1908; Sharma 2014]. At the same time, they are of great typological interest, since their formal and functional development has been influenced by closely related contact languages of the Himachali group.

\section{Demonstratives in New Indo-Aryan languages}

The demonstrative systems of New Indo-Aryan languages are relatively similar; the pronouns, characterized by both attributive and substantive use, function as third-person pronouns and derive from the same stem. As far as can be judged, the demonstrative systems of the majority of New Indo-Aryan languages are based on three reflexes of Old IndoAryan demonstratives, one proximal and two distal.

The proximal demonstratives are considered to go back to Old Indo-Aryan esa 'this' (Table 1, p. 444). In the New Indo-Aryan languages, they usually begin with a front vowel or a diphthong $(i, e, e i)$ as well as the sonant $j$; e.g., Hindi jah (OBL $i s$ ), Bengali $e$, Odia $e$, Maithili $\bar{\imath}$, Nepali jo, Kumaoni jo, Lahnda $e$ (OBL is), Punjabi eh, ih, e, Bhalesi $\bar{\imath}$, etc. [Turner 1962-1985: 122, № 2530].

Descendants of another widespread Old Indo-Aryan proximal demonstrative ayam are found mostly in Dardic and only in some New Indo-Aryan languages [Turner 1962-1985: 26, № 587]. In the course of their historical development, these demonstratives may have been influenced by the reflexes of eșa due to the presence of a front vowel at the beginning of the paradigm forms of both pronouns.

The other two types of demonstratives in the New Indo-Aryan system are distal. The first features pronouns that begin in $s$ - (less often, $t$-) in the direct case and in $t$ - in the other forms. These pronouns derive from the 
Table 1. The declension of the proximal demonstrative eșa in Sanskrit

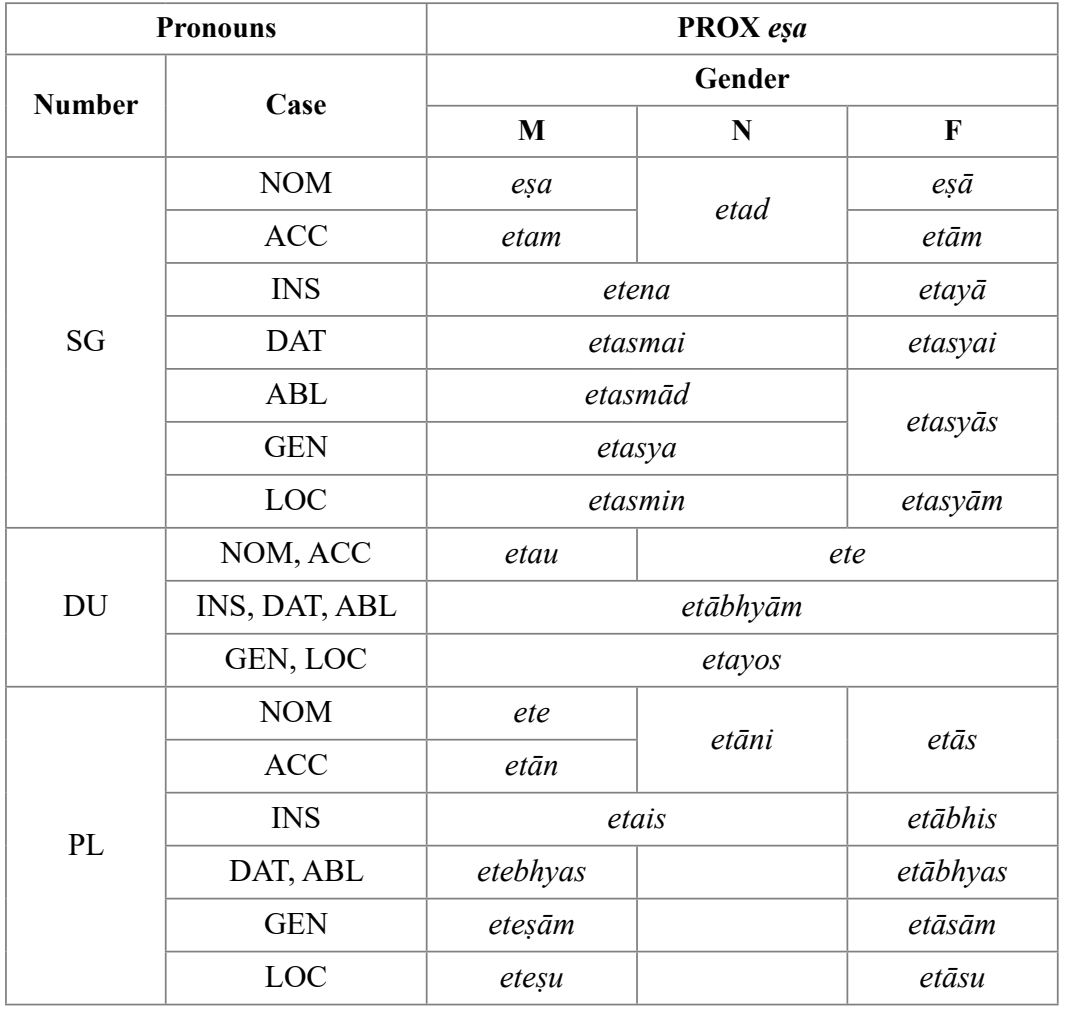

Old Indo-Aryan sa (non-direct stem $t a-$ ) 'that', like Hindi so, Marwari so, Odia se, Maithili se, Marathi to, Nepali tjo, Kumaoni to, Bhalesi sē, Kotgarhi so (OBL tes-), Mandeali se (OBL tes-), etc. [Masica 1991: 225; Turner 1962-1985: 744, № 12815] (see Table 2, p. 445).

Distal demonstratives of the second type have forms with the rounded back vowels or diphthongs $u, o, o u$, as well as with the word-initial sonant $w(\sim b)$; cf. Hindi wah (OBL $u s)$, Lahnda $o$ (OBL $u s, \tilde{u})$, Punjabi $o$ (OBL aus, us), Nepali $u$ (OBL $u s)$, Kumaoni $u$ (in some dialects OBL wi), Old Marwari wo (OBL ũ), etc. [Turner 1962-1985: 43, № 972]. Unlike the reflexes of the Old Indo-Aryan $s a$, the etymology of these 
Table 2. The declension of the distal demonstrative $s a$ in Sanskrit

\begin{tabular}{|c|c|c|c|c|}
\hline \multicolumn{2}{|c|}{ Pronouns } & \multirow{2}{*}{\multicolumn{3}{|c|}{$\begin{array}{c}\text { DIST } s a \\
\text { Gender }\end{array}$}} \\
\hline \multirow{2}{*}{ Number } & \multirow{2}{*}{ Case } & & & \\
\hline & & M & $\mathbf{N}$ & $\mathbf{F}$ \\
\hline \multirow{7}{*}{ SG } & NOM & $s a$ & \multirow{2}{*}{ tad } & $s \bar{a}$ \\
\hline & $\mathrm{ACC}$ & tam & & tām \\
\hline & INS & \multicolumn{2}{|c|}{ tena } & tayā \\
\hline & DAT & \multicolumn{2}{|c|}{ tasmai } & tasyai \\
\hline & $\mathrm{ABL}$ & \multicolumn{2}{|c|}{ tasmād } & \\
\hline & GEN & \multicolumn{2}{|c|}{ tasya } & tasyas \\
\hline & LOC & \multicolumn{2}{|c|}{ tasmin } & tasyām \\
\hline \multirow{3}{*}{ DU } & NOM, ACC & tau & & \\
\hline & INS, DAT, ABL & \multicolumn{3}{|c|}{ tābhyām } \\
\hline & GEN, LOC & \multicolumn{3}{|c|}{ tayos } \\
\hline \multirow{6}{*}{ PL } & $\mathrm{NOM}$ & te & \multirow{2}{*}{ tāni } & \multirow{2}{*}{$t \bar{a} s$} \\
\hline & $\mathrm{ACC}$ & $t \bar{a} n$ & & \\
\hline & INS & \multicolumn{2}{|c|}{ tais } & tābhis \\
\hline & DAT, ABL & tebhyas & & tābhyas \\
\hline & GEN & teșām & & tāsāmm \\
\hline & LOC & teșu & & $t \bar{a} s u$ \\
\hline
\end{tabular}

pronouns is less clear. In [Turner 1962-1985: 43, № 972], they are traced back to the Old Indo-Aryan asau (OBL amu-) 'that', cf. Prakrit aho. However, according to [Masica 1991: 225], as the reflexes of this pronoun are not widely used in Middle Indo-Aryan texts, they cannot account for the sudden and widespread appearance of these forms in New Indo-Aryan languages after the $12^{\text {th }}$ century. C. Masica surmises that this change could have occurred under the influence of Persian. The time period and the area where such forms were used coincide with the Muslim conquests of the northern parts of India, and the formal similarity between the reflexes of asau and the Persian third-person pronoun 
$\bar{o}(\bar{u}$ in modern Farsi) might have triggered the resurgence of the asauderived pronouns.

Table 3. The declension of the distal demonstrative asau in Sanskrit

\begin{tabular}{|c|c|c|c|c|}
\hline \multicolumn{2}{|c|}{ Pronouns } & \multirow{2}{*}{\multicolumn{3}{|c|}{$\begin{array}{c}\text { DIST sa } \\
\text { Gender }\end{array}$}} \\
\hline \multirow{2}{*}{ Number } & \multirow{2}{*}{ Case } & & & \\
\hline & & $\mathbf{M}$ & $\mathbf{N}$ & $\mathbf{F}$ \\
\hline \multirow{7}{*}{ SG } & NOM & asau & \multirow{2}{*}{ adas } & asau \\
\hline & $\mathrm{ACC}$ & amum & & amūm \\
\hline & INS & \multicolumn{2}{|c|}{ amunā } & amuyā \\
\hline & DAT & \multicolumn{2}{|c|}{ amuṣmai } & amuşyai \\
\hline & $\mathrm{ABL}$ & \multicolumn{2}{|c|}{ amuṣmād } & \\
\hline & GEN & \multicolumn{2}{|c|}{ amușya } & amusyās \\
\hline & LOC & \multicolumn{2}{|c|}{ amușmin } & \\
\hline \multirow{3}{*}{ DU } & NOM, ACC & \multicolumn{3}{|c|}{$a m \bar{u}$} \\
\hline & INS, DAT, ABL & \multicolumn{3}{|c|}{ amūbhyām } \\
\hline & GEN, LOC & \multicolumn{3}{|c|}{ amuyos } \\
\hline \multirow{6}{*}{ PL } & $\mathrm{NOM}$ & $a m \bar{\imath}$ & amūni & $a m \bar{u} s$ \\
\hline & $\mathrm{ACC}$ & \multicolumn{2}{|c|}{ amūn } & \\
\hline & INS & \multicolumn{2}{|c|}{ amībhis } & amūbhis \\
\hline & DAT, ABL & \multicolumn{2}{|c|}{ amībhyas } & amūbhyas \\
\hline & GEN & \multicolumn{2}{|c|}{ amīṣām } & amūṣṣam \\
\hline & LOC & \multicolumn{2}{|c|}{ amī̄su } & amūṣu \\
\hline
\end{tabular}

The presence of two distal demonstratives in New Indo-Aryan languages naturally leads to functional competition between them. One pronoun usually functions as distal, while the other acquires an additional meaning; it can become an invisible distant demonstrative, a correlative, a third-person pronoun, or it can disappear completely [Zograf 1976: 160-165; Masica 1991: 224-225]. The languages of the central part of New Indo-Aryan area (Hindi, Braj, Avadhi, Kumaoni, Maithili, 
Bhojpuri, Chhattisgarhi, Punjabi, Lakhnda, Sindhi, Rajastani) use the reflexes of asau as distal demonstratives, while those of the northern (Himachali and Dardic), southwestern (Gujarati, Marathi, Konkani) and eastern (Bengali, Oriya, Assamese) parts prefer the reflexes of $s a$.

Another typologically important distinctive feature of demonstratives in New Indo-Aryan languages is the category of gender. Languages that show gender agreement of adjectives and participles may have no gender-differentiated pronouns, while those with gender-differentiated pronouns may show no gender agreement with adjectives and participles. New Indo-Aryan demonstratives may show no gender at all or have two- or threefold gender distinctions. The reflexes of asau mostly have no gender or distinguish two genders (masculine and feminine). Rather than being inherited from earlier historical stages, the feminine forms are built by analogy [Masica 1991: 224]. Where differentiated for gender, the reflexes of $s a$ can show inherited masculine, feminine, or sometimes even neuter forms. The Old Indo-Aryan neuter gender in nouns is preserved in two groups of languages: the languages of the southeast of India (Gujarati, Marathi, Konkani) and those of the Himachali group (Bhadravahi, Bhalesi, Pangwali). In some Himachali languages (Mandeali, Kiunthali, Kotgarhi), only demonstratives retain the neuter gender. As a common feature, the Himachali languages use the reflexes of $s a$ as distal demonstratives while retaining the Old Indo-Aryan three-gender system.

\section{Inanimate demonstratives in Kullui}

While the system of demonstratives in Kullui includes proximal and distal pronouns, the real difference between them is based not on deixis, but on visibility for the speaker. There are animate and inanimate demonstratives in Kullui. Similarly to adjectives and participles, animate demonstratives have masculine and feminine forms, with twofold contrast shown on non-direct singular forms. These pronouns have both attributive and substantive use and can function as third-person pronouns. Along 
with these, there is a separate set of inanimate demonstratives. These pronouns can also be proximal or distal, they have only substantive use and do not show plural or direct singular forms. The proximal inanimate demonstrative is $\tilde{u} i$ (in some dialects $\tilde{o} i$ ) and the distal demonstrative is $t \tilde{u} i$. The system of demonstratives in Kullui is shown in Table 4.

Table 4. The system of demonstratives in Kullui

\begin{tabular}{|c|c|c|c|c|c|c|c|}
\hline \multicolumn{2}{|c|}{ Pronouns } & \multirow{2}{*}{\multicolumn{3}{|c|}{$\begin{array}{c}\text { PROX }=\text { VIS } \\
\text { Gender }\end{array}$}} & \multirow{2}{*}{\multicolumn{2}{|c|}{$\begin{array}{c}\text { DIST }=\text { INVIS } \\
\text { Gender }\end{array}$}} & \multirow[b]{3}{*}{ INAN } \\
\hline \multirow{2}{*}{ Number } & \multirow{2}{*}{ Case } & & & & & & \\
\hline & & M & F & INAN & M & F & \\
\hline \multirow{3}{*}{ SG } & DIR & \multicolumn{2}{|c|}{$e$} & - & \multicolumn{2}{|c|}{ so } & - \\
\hline & OBL & $e i$ & esa & $\tilde{u} i$ & tei & tesa & tũi \\
\hline & ERG / INS & eie & ese & ũie & teie & tese & tũie \\
\hline \multirow{3}{*}{ PL } & DIR & \multicolumn{2}{|c|}{$e$} & & \multicolumn{2}{|c|}{ te } & \\
\hline & OBL & \multicolumn{2}{|c|}{ inha } & - & \multicolumn{2}{|c|}{ tinha } & - \\
\hline & ERG / INS & \multicolumn{2}{|c|}{ inhe } & & \multicolumn{2}{|c|}{ tinhe } & \\
\hline
\end{tabular}

Though coexistence of inanimate demonstratives along with masculine and feminine demonstratives typologically suggests that masculine and feminine demonstratives only can refer to animate referents, this is not so for Kullui. The masculine and feminine demonstratives in Kulluli can refer to both animate and inanimate objects; cf. (1)-(2):

(1) $\boldsymbol{e}$ mhar-e grã-ri fohri sa esa-be this our-OBL village-GEN girl COP.SG PROX.F.OBL-ACC/DAT mhar-e ghor-a-be fad-at our-OBL house-OBL-ACC/DAT call-IMP.PL

'This is a girl from our village, invite her to our house'.

(2) e sari bohu fobhl-i sa esa-be this saree very good-F COP.SG PROX.F.OBL-ACC/DAT bja-re rodz la-i wedding-GEN.OBL day wear-IMP.FUT 'This saree is very beautiful, wear it on the day of the wedding'. 
The inanimate demonstratives in Kullui have a set of specific functions, the main of which are as follows:

- inanimate demonstratives are used to refer to inanimate objects in combination with all (except the accusative-dative) postpositions. In (3)-(6) below where the masculine, feminine, and inanimate demonstratives have the same antecedent, the masculine and feminine forms are used, respectively, in the direct case, in the oblique case without postposition, and with the accusative-dative postposition, while the inanimate demonstratives occur with other postpositions.

$\begin{array}{llllll}l e & e & \text { pen } \tilde{\boldsymbol{i}} & \text { scnge } & \text { likh } & \text { tzbe } \\ \text { take.IMP } & \text { PROX.DIR pen INAN.PROX INS } & \text { write.IMP } & \text { then } \\ \boldsymbol{e} \boldsymbol{i} & \text { mumbe bapas de-i } & & \\ \text { PROX.M.OBL } & \text { I.ACC/DAT back } & \text { give-IMP.FUT } & & \end{array}$

'Take this pen, write with it and then give it back to me'.

(4)

$\begin{array}{llllll}\boldsymbol{e} & \text { tusar- } i & \text { t } \int a h & s a & \boldsymbol{e s a}-\boldsymbol{b} \boldsymbol{e} & p i \\ \text { PROX.DIR } & \text { your-F } & \text { tea(F) } & \text { COP.SG } & \text { PROX.F.OBL-ACC/DAT } & \text { drink.IMP }\end{array}$

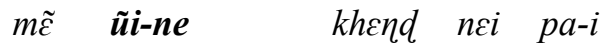

I.ERG INAN.PROX-LOC sugar NEG put-PFV.F

'This is your tea, drink it, I haven't put sugar in it'.

(5)

$\begin{array}{lllll}\boldsymbol{e} & b \varepsilon k s a & s a & \boldsymbol{e i} & d h \supset k-a \\ \text { PROX.DIR } & \text { box } & \text { COP.SG } & \text { PROX.M.OBL } & \text { grasp-IMP.PL }\end{array}$

por ũ andre mota her-d-e

but INAN.PROX inside PROH.PL look-PTCP-PL

'This is a box, take it, but don't look inside it'.

(6)

$\begin{array}{lllllll}d z u \eta & \text { ghor asa } & \text { kotse } & \text { sa } & \text { tui-n } & k o i \\ \text { which } & \text { house } & \text { we.OBL } & \text { near } & \text { COP.SG } & \text { INAN.DIST-LOC } & \text { somebody } \\ n \varepsilon i & \text { roh-nd-a } a & \text { so } & \text { khali } & s a & & \\ \text { NEG } & \text { live-PTCP-M } & \text { DIST } & \text { empty } & \text { COP.SG } & & \end{array}$

'The house that is next to us, no one lives in it, it is empty'.

- inanimate demonstratives are used in non-direct cases where their antecedents are verbal phrases or sentential arguments, see (8)(10). At the same time, the animate demonstratives are used in the direct 
case (7). Referring to verbal phrases or sentential arguments, inanimate demonstratives can also occur in the oblique case (9) or with the accusative-dative postposition (10):

(7) sargit mota pi-nd-e $\boldsymbol{e}$

cigarette PROH.PL drink-PTCP-PL PROX.DIR

sct-ri tẽje fobhl-i nci hu-nd-i

health-GEN.F for good-F NEG be-PTCP-F

'Don't smoke, it is not good for [your] health'.

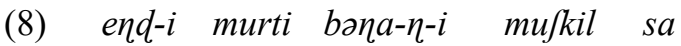

such-F statue make-INF-F difficult COP.SG

ũi-ri tẽje khase rodz lag-a si

INAN.PROX-GEN for many day be_taken-GER COP.PL

'Making such a statue is difficult, it takes many days'.

(9)

$\begin{array}{lllll}\text { gur } & \tilde{\boldsymbol{u} i} & k \varepsilon r \text {-ija } & n i k l-a & s i \\ \text { shaman } & \text { INAN.PROX } & \text { do-CVB } & \text { come_out-GER } & \text { COP.PL }\end{array}$

'By doing this, one becomes a shaman'.

(10)

$\begin{array}{llllll}d z e & d z e & k e l & \text { tokhe } & h u-a & \text { tũi-be } \\ \text { which which } & \text { yesterday } & \text { there } & \text { be-PFV.M } & \text { INAN.DIST-ACC/DAT } \\ t u \quad d \varepsilon s-i & s c k-a & s a & & \\ \text { you tell-CVB } & \text { can-GER } & \text { COP.SG } & & \end{array}$

'Can you tell what happened there yesterday?'

The above-mentioned seem to be the main functions of inanimate demonstratives in Kullui, since they are the most common cases, also confirmed by all my consultants. The fact that demonstratives used with adpositions can formally differ from demonstratives without adpositions is not typologically rare as confirmed, for example, by the so-called pronominal adverbs in Germanic languages. Thus, the German demonstratives $\operatorname{der}(\mathrm{M})$, die (F), das $(\mathrm{N})$ in substantive use do not combine with prepositions where their antecedents are inanimate nouns. Special pronominal adverbs with the initial formants $d a$ - or $d a r$ - are used instead, cf. dafür ( $\leftarrow$ für das) 'for this', etc. ${ }^{1}$

\footnotetext{
${ }^{1}$ I am grateful to Maria Kholodilova who drew my attention to this fact.
} 
Other uses of inanimate demonstratives in Kullui require further study. In particular, these include several cases, confirmed by some native speakers:

- inanimate demonstratives can be used in non-direct cases where their antecedents are nouns with non-specific (generic) reference.

$\begin{array}{llllll}\text { (11) } & \text { mer-a } & \text { fohru mathjai } & \text { bohu pesand } & k \varepsilon r-a \\ \text { my-M } & \text { son } & \text { sweets } & \text { very preferable } & \text { do-GER } \\ \text { sa } & \text { par dekter-e tei-be } & & \\ \text { COP.SG } & \text { but doctor-ERG } & \text { DIST.OBL-ACC/DAT } & \end{array}$

$\begin{array}{llll}\boldsymbol{t u \tilde { i }} & k h a-n-e-b e & n a & k \varepsilon r-u \\ \text { INAN.DIST } & \text { eat-INF-OBL-ACC/DAT } & \text { refuse } & \text { do-PFV.M }\end{array}$

'My son loves sweets very much, but the doctor forbade him eating them'.

— inanimate demonstratives refer to the word kahani 'story' in non-direct cases. Most likely, the reason is that this word semantically correlates with a set of events like a sentential argument. Probably, there is a set of such words, but my data currently contain only one example:

$\begin{array}{llll}\text { (12) } & e \quad \text { fobhl-i } & \text { kahani } & \text { sa } \\ \text { PROX.DIR good-F } & \text { story } & \text { COP.SG } \\ \text { ui-be } & d z a r u r & \text { por- } i \\ \text { INAN.PROX-ACC/DAT } & \text { surely read-IMP.FUT } \\ \text { 'This is a beautiful story, surely read it'. }\end{array}$

Despite the wide use of inanimate demonstratives in Kullui, their description is either lacking in the existing reviews as in [Diack 1896; Bailey 1908; Sharma 2014], or is very sketchy [Grierson 1916; Thakur 1975; Ranganatha 1981].

Grierson [1916: 670-687] characterizes Kullui demonstratives as follows: "They (demonstrative pronouns) have feminine forms in the singular, but nothing corresponding to the neuter forms of the Simla dialects has been noted". Further, the text provides a table of the declension of demonstratives showing only masculine and feminine forms. However, Grierson mentions another demonstrative encountered in a sample from a Kullui text, the "Parable of the Prodigal Son" "2: "In the specimen

\footnotetext{
${ }^{2}$ Grierson's work contains translations of this text into many languages.
} 
the form $u \bar{\imath}$ or $o \bar{l}$ (once in each form) occurs instead of tei . The phrase is $u \bar{\imath}(o \bar{l}) j \bar{o} g \bar{a} n a h \bar{\imath}$ (INAN worthy NEG), I am not worthy of that" [Grierson 1916: 675]. The quote with this demonstrative is not complete; in the text, the sentence ends with a dependent clause je phiri têra $\bar{a}$ beț $\bar{a}$ $b \bar{o} l-n \bar{u}$ (that again your son say-FUT.1SG) 'to be called your son again'. Thus, an inanimate demonstrative in the text sample has a sentential argument as an antecedent.

In [Thakur 1975: 258], the inanimate demonstrative $\tilde{u} i$ is mentioned, which, according to the author, is found in only some areas of the Kullu district. He gives no further information about $\tilde{u} i$ and no mention of the distal inanimate demonstrative tũi, nor provides examples of their use. Ranganatha [1981: 90] makes the following remark on the third-person pronouns: "Pronouns in singular show a three way distinction of masculine, feminine and neuter. This distinction appears to be purely semantic and they do not seem to have any bearing on the general set up of two way gender distinction made elsewhere". This phrase, however, is the only mention of neuter pronouns in the work; nor does the author include them in the table showing the declension of demonstratives.

\section{Inanimate demonstratives in other Himachali languages}

Although never studied in Kullui before, inanimate demonstratives are noted in other Himachali languages. For example, Hendriksen [1986: 115-116] describes inanimate demonstratives in Kotgarhi and Kochi, while Grierson [1916: 566] discusses such pronouns in Kiunthali. The functions of such pronouns are not studied in detail, but in all three languages, these demonstratives can only be used substantively and refer to only inanimate objects. However, unlike Kullui, inanimate demonstratives in these languages are reflexes of Old Indo-Aryan neuter pronouns. Similar neuter demonstratives are also noted in Shimla Siraji [Grierson 1916: 594] and Mandeali [Ibid.: 723; Ranganatha 1981: 38]. 
Table 5. The system of demonstratives in Kiunthali [Grierson 1916: 566]

\begin{tabular}{|c|c|c|c|c|c|c|c|}
\hline \multicolumn{2}{|c|}{ Pronouns } & \multirow{2}{*}{\multicolumn{3}{|c|}{$\begin{array}{l}\text { PROX } \\
\text { Gender }\end{array}$}} & \multirow{2}{*}{\multicolumn{3}{|c|}{$\begin{array}{c}\text { DIST } \\
\text { Gender }\end{array}$}} \\
\hline \multirow{2}{*}{ Number } & \multirow{2}{*}{ Case } & & & & & & \\
\hline & & $\mathbf{M}$ & $\mathbf{N}$ & $\mathbf{F}$ & $\mathbf{M}$ & $\mathbf{N}$ & $\mathbf{F}$ \\
\hline \multirow{3}{*}{ SG } & DIR & \multicolumn{3}{|c|}{$\bar{e} h$} & \multicolumn{3}{|c|}{$s \bar{e}$} \\
\hline & OBL & $\breve{e s}$ & ĕtthī & $\breve{e s s o ̄}$ & tĕs & tĕtthī & tĕssō \\
\hline & ERG & \multicolumn{2}{|c|}{$i n \bar{\imath} \bar{e}$} & ĕssē & \multicolumn{2}{|c|}{ tinīe } & tĕssēe \\
\hline \multirow{3}{*}{ PL } & DIR & \multicolumn{3}{|c|}{$\bar{e} h$} & \multicolumn{3}{|c|}{$s \bar{e}$} \\
\hline & OBL & \multicolumn{2}{|c|}{$\bar{\imath} h n \bar{o}$} & $\bar{\imath} h n \bar{\imath}$ & \multicolumn{2}{|c|}{ tīhnō } & $t \bar{\imath} h n \bar{\imath}$ \\
\hline & ERG & \multicolumn{2}{|c|}{$\bar{\imath} h n \bar{e}$} & $\bar{i} h n \bar{\imath} \bar{e}$ & \multicolumn{2}{|c|}{ tìhnnē } & tīhnīe $\bar{e}$ \\
\hline
\end{tabular}

Table 6. The system of demonstratives in Mandeali [Ranganatha 1981: 38]

\begin{tabular}{|c|c|c|c|c|c|c|c|}
\hline \multicolumn{2}{|c|}{ Pronouns } & \multirow{2}{*}{\multicolumn{3}{|c|}{$\begin{array}{l}\text { PROX } \\
\text { Gender }\end{array}$}} & \multirow{2}{*}{\multicolumn{3}{|c|}{$\begin{array}{c}\text { DIST } \\
\text { Gender }\end{array}$}} \\
\hline \multirow{2}{*}{ Number } & \multirow{2}{*}{ Case } & & & & & & \\
\hline & & M & $\mathbf{N}$ & $\mathbf{F}$ & M & $\mathbf{N}$ & F \\
\hline \multirow{3}{*}{$\mathrm{SG}$} & DIR & \multicolumn{3}{|c|}{ je } & \multicolumn{3}{|c|}{ se } \\
\hline & OBL & jes & jetta & jessa & tes & tetta & tessa \\
\hline & ERG & inne & jette & jesse & tinne & tette & tesse \\
\hline \multirow{3}{*}{ PL } & DIR & \multicolumn{3}{|c|}{$j \tilde{o}$} & \multicolumn{3}{|c|}{ sjõ } \\
\hline & OBL & \multicolumn{3}{|c|}{ innha } & \multicolumn{3}{|c|}{ tinnha } \\
\hline & ERG & \multicolumn{3}{|c|}{ innhe } & \multicolumn{3}{|c|}{ tinnhe } \\
\hline
\end{tabular}

All the Himachali languages above that retain neuter demonstratives only distinguish masculine / feminine nouns, having lost the Middle IndoAryan neuter gender. This, naturally, changed the function of neuter demonstratives that had formerly referred to neuter nouns. I could not find a detailed analysis of these functions in any of the descriptions of Himachali but for some isolated remarks. In particular, Hendriksen [1986: 115116] compares inanimate demonstratives, used with postpositions, to English pronominal adverbs (therefore $\leftarrow$ for that, thereto $\leftarrow$ to that, etc.). 


\section{Formation of inanimate demonstratives in Kullui}

As far as one can judge, the inanimate demonstratives in Kullui are functionally comparable to neuter demonstratives in other Himachali languages. However, in contrast to animate demonstratives, they do not descend from the Old Indo-Aryan neuter gender forms of eșa 'this' and $s a$ 'that' (etad and tad, respectively). The pronoun $\tilde{u} i$ formally resembles a reflex of another Old Indo-Aryan distal demonstrative, asau. According to Hendriksen, the reflexes of asau are not used in Himachali languages (though he classifies as Himachali only a limited number of languages, viz. Sirmauri, Jaunsari, Baghati, Kiunthali, Kotgarhi, Kochi, Mandeali and Kullui [Hendriksen 1986: 3, 115]). At the same time, reflexes of asau are common in Chambeali, Gaddi, Churahi, Pangwali, Bhadravahi, and Bhalesi that are located northeast of the languages listed by Hendriksen and are usually included into the Himachali group either. Moreover, in Pangwali and Bhadravahi the reflexes of $s a$ and asau, according to grammatical descriptions, have similar functions and are probably interchangeable [Grierson 1916: 779, 798, 823-824, 851, 891; Dwivedi 2015: 136]. Reflexes of asau are also found in Suketi, a language bordering on Kotgarhi and Mandeali, not mentioned in Hendriksen's work; Suketi uses the pronoun $\bar{o} h$ (OBL $u s$, ERG une $<a s a u$ ) alongside $s \bar{e}(<s a)$ as a distal demonstrative [Grierson 1916: 757]. Thus, reflexes of asau could be preserved in Kullui.

Kullui borders on Mandeali in the west and on Sainji and Inner Siraji in the south. Tibeto-Burman languages are spoken in the east and northeast of Kullui, with the rugged mountainous terrain in the northwest minimizing the options for language contact. Mandeali has inherited neuter demonstratives (Table 6). Sainji and Inner Siraji remain largely undescribed, with Grierson [1916: 691, 702] characterizing them as languages without neuter demonstratives. The Inner Siraji text sample from the 'Parable of the Prodigal Son', however, contains the phrase teta jogi nahi rauhu (INAN worthy NEG stay.PFV) 'I am not worthy of that (to be called your son)', similar to the one where the demonstrative $\tilde{u} i$ is used in Kullui. This phrase features the form teta, etymologically a neuter distal demonstrative (cf. Mandeali 
tetta). Thus, Kullui finds itself surrounded by closely related Himachali languages, in which the neuter demonstratives are well preserved.

Based on the above, I suggest that, while the original neuter demonstratives have been lost in Kullui, the rarely used reflex of asau has taken over the neuter pronoun functions, still retained in the neighbouring Himachali contact languages. Since neuter demonstratives distinguish proximal and distal meanings, the pronoun tũi derived from $\tilde{u} i$ by analogy with the rest of the paradigm where distal demonstratives formally differ from proximal demonstratives by only the initial $t$-. The fact that, while $\tilde{u} i$ is mentioned in several grammatical descriptions of Kullui, tũi does not appear in any of them, also confirms the secondary nature of tũi. Thus, the reflex of asau and the new word derived from it by analogy replace the former neuter pronouns in the system of the demonstratives of Kullui.

\section{Conclusion}

Inanimate demonstratives in Kullui (the proximal $\tilde{u} i$ and the distal tũi) have only non-direct singular forms and can refer to inanimate nouns, verbal phrases, or sentential arguments. In many cases, combinations of these demonstratives with postpositions are similar to pronominal adverbs in Germanic languages. Other Himachali languages also have inanimate demonstratives that etymologically descend from the Old Indo-Aryan neuter pronouns. Since nouns in most Himachali languages do not distinguish the neuter gender, their neuter demonstratives have acquired new functions. However, in Kullui, inanimate demonstratives do not go back to neuter pronouns. While other demonstratives in Kullui derive from the Old Indo-Aryan pronouns eșa (proximal) and $s a$ (distal), the inanimate proximal demonstrative $\tilde{u} i$ goes back to the Old Indo-Aryan distal pronoun $a s a u$, whereas the distal pronoun tũi is formed directly from $\tilde{u} i$ by analogy. Presumably, this happened because Kullui, having lost its original neuter demonstratives, developed a new system based on the rarely used reflex of asau under the influence of its neighbouring closely related languages that have retained their neuter demonstratives. 


\section{Abbreviations}

$1-1^{\text {st }}$ person; ABL - ablative; ACC - accusative; ACC/DAT - accusative-dative postposition; COP - copula; CVB - converb; DAT — dative; DIR - direct; DIST - distal demonstrative; DU - dual; ERG - ergative; F — feminine gender; FUT — future tense; GEN - genitive; GER - gerund; IMP — imperative; INAN — inanimate; INF infinitive; INS - instrumental; INVIS - invisible; LOC - locative; M - masculine gender; $\mathrm{N}$ - neuter gender; NEG — negative particle; NOM — nominative; OBL — oblique; PFV - perfective; PL — plural; PROH — prohibitive particle; PROX — proximal demonstrative; PTCP — participle; SG - singular; vIS — visible.

\section{References}

Bailey 1908 - T. G. Bailey. The Languages of the Northern Himalayas, Being Studies in the Grammar of Twenty-Six Himalayan Dialects. (Asiatic Society Monographs 12). London: Royal Asiatic Society, 1908.

Diack 1896 - A. H. Diack. The Kulu Dialect of Hindi: Some Notes on Its Grammatical Structure, with Specimens of the Songs and Sayings Current amongst the People, and a Glossary. Lahore: The "Civil and Military Gazette" Press, 1896. Dwivedi 2015 - A. V. Dwivedi. Bhadarwahi: A typological sketch. Acta Linguistica Asiatica. 2015. Vol. 5. Iss. 1. P. 125-148. DOI: 10.4312/ala.5.1.125-148.

Grierson 1916 - G. A. Grierson. Linguistic Survey of India. Vol. 9: Indo-Aryan Family: Central Group. Pt. 4: Specimens of the Pahārī Languages and Gujurī. Delhi: Varanasi Patna, 1916.

Hendriksen 1986 - H. Hendriksen. Himachali Studies. Vol. 3: Grammar. (Historisk-Filosofiske Meddelelser 48, 3). Copenhagen: Regia Academia Scientiarum Danica, 1986.

Masica 1991 - C. P. Masica. The Indo-Aryan Languages. (Cambridge Languages Surveys). Cambridge: Cambridge University Press, 1991.

Ranganatha 1981 - M. R. Ranganatha. Survey of Mandeali and Kului in Himachal Pradesh. (Census of India, 1971. Series 1: India. Language Monograph 7). Delhi: Language Division, Office of the Registrar General, India, 1981.

Sharma 2014 - D. Sharma (Saraswat). Kuluti-Hindi vyakaran. Ek tulnatmak adhyayan [Kuluti and Hindi Grammar. A Comparative Analysis]. New Delhi: Lekhni, 2014.

Thakur 1975 - M. R. Thakur. Pahari bhasha kului ke vishesh sandarbh men [The Pahari Language with Special Reference to Kului]. Delhi: Sanmarg Prakashan, 1975. 
Turner 1962-1985 - R. L. Turner. A Comparative Dictionary of Indo-Aryan Languages. London: Oxford University Press, 1962-1966. Includes three supplements, published 1969-1985. Available at: http://dsal.uchicago.edu/dictionaries/ soas/ (accessed on 17.03.2021).

Zograf 1976 - G. A. Zograf. Morfologicheskiy stroy novykh indoariyskikh yazykov: opyt strukturno-tipologicheskogo analiza [Morphological Structure of New Indo-Aryan Languages: An Attempt of Structural and Typological Analysis]. Moscow: Nauka, 1976. 